\title{
The Current Condition of Indonesian Literature Teachers: A Study about Student' s Constraints in Learning Writing Creative Literature
}

\author{
M. Firdaus ${ }^{1}$, Yohannes Telaumbanua ${ }^{2}$ \\ ${ }^{1}$ STKIP Rokania, Pekanbaru, Indonesia, ${ }^{2}$ Politeknik Negeri Padang, Padang, Indonesia \\ *Corresponding author, e-mail: firdaus.fauzy@ymail.com
}

\begin{abstract}
As prospective teachers, the students of the Indonesian Language and Literature Education Study Program must have sufficient literary skills and experience of writing literature works. The facts are, however, very different. To date, most students face varied kinds of obstacles to writing literature works. Writing literature works require lofty creativity and imagination to produce the Dulce Et Utile (radiating the beam of the aesthetic and educational values of the works). The purpose of this study was, therefore, to describe the factors that become the students' major obstacles to writing literature works. The method used was the qualitative descriptive whilst the observation, interview, and document analyses were the techniques of data collections. The 21 subjects of this study were the sixth-semester students of undergraduate Indonesian Language and Literature major at the Islamic University of Riau (UIR). The results of this study indicated that the factors that become the students' crucial obstacles to learning Writing Literature Works were the lecturers' unprofessionalism (centered-staged with different discipline/area of study of lecturers), lack of respect to the Writing Literature Works' course; limited number of credit course, continue transmitting theoretical knowledge rather than keep practicing/writing the works, and the inappropriate teaching/learning model used in the Writing Literature Works' course. As a result, these factors is a form of the implementation of learning writing literature works is still a formality and certainly prevent the students of being professional teachers.
\end{abstract}

Keywords: Writing Creative, Literature Learning, Prospective Teachers

How to Cite: Firdaus, M., \& Telaumbanua, Y. (2018). The Current Condition of Indonesian Literature Teachers: A Study about Student' s Constraints in Learning Writing Creative Literature. International Journal of Research in Counseling and Education, 2(2) 71- 76, https://doi.org/10.24036/0025za0002

\section{Introduction}

The success of learning literature at schools exceptionally depends on the teachers' knowledge and skills of teaching literature to thestudents. The better the teachers' quality has in teachingliterature, the better the students understand and master the literary works. On the contrary, the research findings disclosed that the conditions of teachingliterature (literary works) in educational institutions have not optimally run for many years now and certainly, it is terribly apprehensive about the future of learning literature at schoold.(Rudy, 2002; Kimtafsirah, 2003; Newadi, 2005; Imron, 2007; Herfanda, 2007; Trianton, 2008; Tarigan, 2008; Mahayana, 2008; Suyatno, 2010; and Nuryanti et.al., 2016). Many Indonesian practitioners and observers appraised the teaching of literature at schools is monotonous, unattractive, and even boring.

As previously stated, the research findings adducedthat the major factor of teachers' failure to teach literature is the teachers' unprofessionalism and lack of creativity. Whereas, Most of the Indonesian language and literature teachers were born, well prepared and ordered from mastering the skills and knowledge in the Faculty of Teacher Training and Education. Of course, the related major teaching materials on education, linguistics and literature have been studied since the beginning of the semester. They should have already had betterskills, knowledge and experience of teaching literature. Thus, there is no an excuse for or a reason for Indonesian teachers to not to master the literature. The first public impression is that they are qualified teachers. 
Knowledgeable and skillful literary teachers in general have various requirements. The requirements are (1) mastering literature literary material, (2) understanding the essences and the objectives of teaching literature including able and skilled at appreciating literary works, (3) having critical thinking in analyzing literary works, (4) mastering methods of teaching literature and (6) having a particular views of philosophy of life because literature is the experience of the human soul served to the students to enrich their life experiences and shape or form their personality (Purba, 2008).

Subana and Sunarti (2009) state that literary teaching aims at gaining experience and mastering knowledge of literature. To gain literary experience, the students must experience directly that is by reading or listening to literary works. Writing literature is the practical ways of appreciating and expressing the literary works.

For writing activities, it decidedly requires creativity so that the literary works the students produce can be Dulce Et Utile. The function of entertaining (Dulce) means the literature provides its own pleasure to the readers so that they feel interested in reading literature. The function of teaching (Utile) means that literature gives advice and ethical inculcation so that the readers can imitate the positive values in the literary works. In this sense, the literature enables human beings to become more human: to know oneself and others, to the environment, and to the various life issues (Sarumpaet, 2010).

During the lectures of literature, many students have difficulty when given the task of writing literary works (Setyaningsih, 2010). If so, what will happen to the Indonesian language and literature' s prospective teachers? Do they have enough knowledge and skills to become teachers if they have such lecturers? Supposedly, the fruit of literary teaching is "the person who matures the tree", not force to be an instant teacher (Oemarjati, 2010).

The purpose of this research is to describe the factors that become students' obstacles of writing literature. Indirectly, the research results will also describe how the role done by colleges that educate prospective literature teachers. The results of this study are expected to be used as an alternative solution to the decision-making in solving problems related to the constraints in writing literature, can be used as the additional library repository, the reference materials and the inputs of further research, related to the problems that exist in the literary' s learning at the University.

\section{Method}

The method used in this research was the descriptive qualitative while the observation, interview, and document analysis were techniques of data collection. The sample of research used as a source of data was students majoring in the IndonesianLanguage and Literature at the Islamic University of Riau (UIR) who took the course of Literature Writing Learning was students of 2015 academic year amounting to 21 research respondents. The UIR' s Faculty of Teacher Training and Education of IndonesianLanguage and Literature in Pekanbaru is the only university offering this course. The special curriculum of literature' s learning for writing literature course is only offered at the Islamic University of Riauwhile at the University of Riau, the course has been totally dispensed.

\section{Results and Discussion}

The results of this study indicated that the factors that become the students' crucial obstacles to learning Writing Literature Works were the lecturers' unprofessionalism (centered-staged with different discipline/area of study of lecturers), lack of respect to the Writing Literature Works' course; limited number of credit course, continue transmitting theoretical knowledge rather than keep practicing/writing the works, and the inappropriate teaching/learning model used in the Writing Literature Works' course.As a result, these factors is a form of the implementation of learning writing literature works is still a formality and certainly prevent the students of being professional teachers. The followings were the details.

\section{The lecturers' unprofessionalism}

One of the students' considerations of choosing a college is quality. One of the quality expected by students in choosing a college is the quality of lecturers. A qualified lecturer is a professional lecturer. Professional lecturers will be able to produce qualified graduates. However, based on the results of interviews with the students, themajor obstacle to learning to write a literary work is the unprofessional lecturers who teach it. The causesare as follows.

The lecturers do not have a work commitment. The students feel disappointed because the lecturers who teach this course is often not being on time; the class (teaching) is not on schedule; when not able to teach, 
the lecturer does not inform the students; and sadly, the lecturer tend to change the course' s schedule at will,

The lecturer' s objectivity in assessing the students' learning outcome. The lecturers usually give high marks to students who are closer to them. The tasks/assignments given were only to meet the course' $s$ requirements.

The lecturers often leave the class because of having bustling activity. The main reason the lecturers do not teach is because of theirflurry of activity that can not be left behind. Moreover, the lecturers who teach the course ' Writing the literary works' is not a permanent lecturerS from the Islamic University of Riau.

The lecturers who have such an ineffective personality obstruct the effectiveness of learning. Having such bad habits will automatically affect the quality of learning. Dantes (2012) describes that the educator is an intact educator who viewed from three perspectives, namely the brain, body, and heart. Viewed from the brain, professional educator is an expert in the field that is taught. Viewed from the body, a professional educator has the appearance as an educator who became a model, while the heart, it refers to the sincerity of the heart in providing educational servicesso that the educator becomes a teacher in the heart of his/her students. The lecturers as professional educators must be able to animate and transform the various values of life both hard and soft skills in the life and growth of his/her students' life (Dantes, 2011). Do not let the professional form is only obtained through the proof of this educator certificate without being offset by the application of Tri Dharma Perguruan Tinggi, which has become the guideline to run his/her professions.

\section{Writing literature works is just as an elective course}

The curriculum material is not merely a collection of knowledge but must be a single unified knowledge that is meaningful, whether it is in knowledge or for students and the environment (Sukmadinata in Depdiknas, 2009). That is why curriculum materials need to be adapted to the characteristics of student development and modern concepts about the nature of learning(Depdiknas, 2009).

Based on the results of the interviews with the students, the subjects of Writing Literature is only as a subject of choice so that for them this subject is less important because it is not a suject that must be mastered in the lecture. Students stated that it makes them less motivated to study the Writing of Literature.

In the academic system, the lectures have been well organized. It even hasalready formedcertain divisions. So that it arises an indirect separation between language education and literary education, which is made with a system to choose one of them, but we know that the essence of language and literature is a unity. The phenomenon of the dichotomy of language and literature in the study of Indonesian language and literature is held, perhaps with the aim of exploring the potential of students in the field of language or in the field of literature.

In fact, it turns out that curriculum development in universities often does not have a proportional comparison. Based on the results of document analysis, the developmentof curriculum of Indonesian Language and Literature in UIR focuses more on the linguistic aspects. The existence of this phenomenon, of course, can be one cause, the provision of literary skills possessed by prospective teacher of literature to be inadequate. It is enough to consider if, for example, of the 150 credit courses taken by the students during studying at the college, it turns out that only 15 - 20 credits which are related to literature.

The selection of curriculum materials that suits the educational needs considers three things: 1) outlining educational goals into specific and measurable forms of results; 2) learning materials include knowledge, skills, and holistic attitudes; 3) learning materials should be arranged systematically and logically in accordance with the stage of development of learners (Widyastono, 2014).If the learning results are generally formulated, the formulation of learning experiences will be difficult to do.

\section{Limited number of credit course}

The Literature Writing has 2 credit Courses with the learning achievement is that students are able to master the basic concepts of literary writing and master the concept of the various benefits of writing to foster the interest in and motivation to write, understand and have a wealth of language, imagination, and sensitivity of feeling and sensitivity towards the environment as an assets that the creative writers must possess, understand and be able to perform the stages of the creative process, understand the structure of a good and interesting story and can arrange it in the form of prose-fiction work, understand the poetic experience as the basis of writing poetry, understand the ways of sharpening and cultivating elements of poetry builders, writing fiction works of short stories, writing poetry, and drama. With the achievement of learning is expected quite a lot and accompanied by a little time, will be impossible to achieve maximum learning. Since the allocation of time for this literary lesson is less, how could a teacher be able to give a 
perfect literary teaching when the time is limited. The impact of at least the time of teaching literature, causes lecturers are to provide more literature lessons by memorizing and not with the appreciation of literature.

This condition is very detrimental in the process of learning literature that takes a lot of time if the target reaches on affective level. Learning literature is not enough only to understand theoretically, but it requires a long process to be able to arouse talent and interest, so that literary learning can develop as something fun, although it is believed most of the lecturers consider it as something relatively impposible.

\section{Literature Writing is more theoretical than practice}

The implementation of writing literature based on the syllabus of Creative Writing Literature in the Indonesian Education Studies Program FKIP UIR emphasizes the theory aspect. Of the 16 meetings, only 3 meetings emphasize the practice of literary learning. That is, the implementation of literary learning remains the same as the condition of literary learning from previous years, still directed to the cognitive intelligence (Salam, 2008; Suryaman, 2010; and Nuryanti et.al., 2016). Teachers are still focused on conveying theories that bind the creation and interpretation of literary works (Marantika, 2014). This kind of learning process will only produce students who tend to understand literature secaratoritis, without being able to appreciate it well.

The lectures that emphasize the practice of learning literature were also divided into 3 activities, namely writing short stories, poetry, and drama script. In fact, such writing activities require more effort and time. To get used to writing, it can be done by reading, discussing with friends or others, attending seminars, watching events that happen in our daily lives(Setiaji dalam kuncoro, 2009).

\section{The teaching model used by the lecturer has not been able to optimize the learning}

of writing the literary works

Based on the observation, the lecturer's learning process is always tied up with rigid learning ethics, as it relies heavily on textbooks used, and other learning media including the syllabus, limiting their creativity in determining appropriate learning methods and techniques that can improve the motivation of learners. As the lesson progresses, the lecturers prefer the lecture method by focusing on the PowerPoint slides made by the lecturer.

A lecturer in delivering the subject matter needs to choose which method suits the students so that they feel interested in following the lesson being taught. However, in the process of learning, lecturers still use conventional methods or tend to provide continuous material without involving the students or without providing opportunities for students to argue and express opinions, so that students become less active in the process of learning in class.

Sukatman (2009) states that the success of literary learning depends not only on the quantity of learning alone, but also determined by its intensity. Therefore, the most important thing in the learning of literature is how to seek the learning of literature in depth, to touch the feelings of learners, favored, and not too burdened by the excessive theories. One alternative that can be used is the selection of the right learning model. Learning model should be adjusted with the material discussed, the condition of students, situations, and learning support facilities, do not forget the ability of lecturers in mastering the learning model. A teacher should master the condition / characteristics of learners who are taught and served deeply with a variety of characters and approaches(Dantes, 2012).

The selection of the right learning model will determine the interest and participation of students in learning. Through the right model of learning is expected that students not only get knowledge but also a deep impression of literature lessons that can encourage students to implement in everyday life. Lecturers need to hold variations in teaching students. Skills in variation in the teaching and learning process will include three aspects: variation in teaching style, variations in media use and teaching materials, and variations in the interaction between faculty and students. If the three components are combined in their use or in an integrated manner, it will increase student attention, arouse the desire and willingness to learn. Thus, professors' teaching variations significantly influence the student learning outcomes(Ibadi, 2009).

\section{Conclusion}

The process of literary learning, especially on creative literature learning should be done by focusing on developing students' potential so that they gain knowledge and skills as prospective teachers in the future. Writing literature requires the appreciation of the experience to be expressed, the mastery of literary writing 
techniques, and has a broad insight into the aesthetics. Factors that become the main obstacle of students in learning to write a literary work is a form of the implementation of literature learning is still a formality and will hinder students become professional teachers. If this continues to happen in the world of education in college, of course, we will always get the teachers of literature that is not qualified. The role of college is very important in managing students to be educated to be a professional teacher. For teachers who have taught learning literature, should begin to fix them by improving the quality of the self so that the expected learning objectives in the world of education can maximally run.

\section{Acknowledgment}

Acknowledgments to the Chairman of the Indonesian Language and Literature Education Study Program Faculty of Teacher Training and Education University of Riau who have given permission in the implementation of this research, along with lecturers, and students who were willing to take the time to be interviewed.

\section{References}

Baruadi, M. K. (2005). " Profil pengajaran sastera (wacana pengembangan pengajaran sastera berbasis kawasan)" dlm. Jurnal pendidikan dan kebudayaan. Universitas Negeri Gorontalo. 25:274.

Dantes, N. (2011). Pembinaan Guru Profesional Berbasis Karakter (Suatu Rangkaian Perspektif dan Kebijakan Pendidikan Menghadapi Tantangan Global). Materi Pendidikan dan Latihan Profesi Guru. Singaraja:Universitas Pendidikan Ganesha.

Dantes, N. (2012). Profesi Guru Dalam Kaitannya Dengan Peningkatan Profesionalisme Guru (Refleksi Tentang Struktur Program LPTK). (Online),(http://nyomandan-tes.wordpress.com/page/2/,diakses tanggal 27 Januari 2018)

Depdiknas.(2009). Perkembangan Kurikulum SMP. Jakarta: Dirjen Dikdasmen.

Herfanda, Ahmadun Yosi. (2007). " Menuju Format Baru Pengajaran Sastra” , dalam Makalah Seminar Pengajaran Bahasa dan Sastra dalam Gebyar Bahasa dan Sastra Indonesia 2007, HMBSI FPBS UPI Bandung, 10 April 2007.

Ibadi, Mahfud, Murdani, dan Al janan. (2009). “ Pengaruh Persepsi Mahasiswa Tentang Variasi Mengajar Dosen Terhadap Hasil Belajar Dalam Mata Kuliah Teknik Permesinan” dlm. Jurnal Fakultas Teknik, Universitas Negeri Semarang. 9:1, 50 - 55.

Imron, A. (2007). Pembelajaran sastera multikultural di sekolah: Aplikasi novel burung-burung rantau. Kajian linguistik dan sastera. PBSID-FKIP-UMS. 19:1. 60-75.

Kimtafsirah. (2003). Meningkatkan Apresiasi Sastra dengan Strategi Respons Pembaca dalam Konteks Indonesia. Makalah disajikan pada Seminar Nasional Paradigma Baru Pengajaran Sastra FKM Program Pascasarjana UPI.

Kuncoro, Mudrajad. (2009). Mahir Menulis Kiat Jitu Artikel, Opini, Kolom dan Resensi Buku. Jakarta: Erlangga.

Mahayana, M. S. (2008). "Apresiasi Sastera Indonesia di sekolah" dlm. Jurnal Pemikiran Alternatif Pendidikan. INSANIA. 13:3. 382-393.

Marantika, Juliaans E. R.(2014).“ Drama dalam PembelajaranBahasa dan Sastra” , dlm. Jurnal TahuriUniversitas Pattimura, ejournal.unpatti.ac.id.11:2, 91-102.

Nuryanti, Mira et.al. (2016). " Pengembangan Model PembelajaranBerbasis Proyek dalam Pembelajaran SastraPada Siswa Kelas VIII SMP Sekabupaten Cirebon” , dlm. Jurnal METASASTRA. 9:1, 53—66.

Oemarjati, Boen S. (2010). Dengan Sastra Menapaki Proses Kreatif sebagai Basis Ketangguhan Watak. Makalah Utama Seminar Internasional PIBSI 32. Yogyakarta: Unwidha.

Purba, Antilan. (2008). Stilistika Sastra Indonesia Kaji Bahasa Karya Sastra. Medan: USU press

Rudy, Rita I. (2002). " Pengembangan Kualitas Pembelajaran Sastra sebagai Seni Bahasa dalam menggali Nilai-nilai Budaya di Perguruan Tinggi. Makalah. Dipresentasikan dalam Forum Sastra dan Budaya II di UPI Bandung, 24-26 Oktober 2002. 
Salam, Aprinus. (2008).“ Pengajaran Sastra dan Politik Kebudayaan dan Politik Kebudayaan” , dlm. Jurnal INSANIA P3M STAIN Purwokerto. 13: 3, 369-381.

Sarumpaet, R.K.T. (2010). Pedoman Penelitian Sastra Anak: Jakarta: Pusat Bahasa Kementrian Pendidikan Nasional.

Setyaningsih, Nas Haryati. (2014). “ Model Kolaboratif Tipe Investigasi Kelompok sebagai Upaya Peningkatan Kemampuan Apresiasi Prosa Mahasiswa” dlm. Jurnal Lingua. X:1, 48-56.

Subana, M dan Sunarti.(2009). Strategi Belajar Mengajar Bahasa Indonesia. Bandung: Pustaka Setia.

Sukatman. (2009). Butir-butir Tradisi Lisan Indonesia Pengantar Teori dan Pembelajarannya. Yogyakarta: LaksBang

Suryaman, M. (2010). “Pendidikan karakter melalui pembelajaran Sastera” dlm. Jurnal Cakrawala Pendidikan. Edisi Khusus Dies Natalis UNY.

Suyatno. (2010). Pemanfaatan novel karya anak untuk pembelajaran sastera di sekolah dasar. Jurnal Pendidikan Dasar. 11:1. 81-92.

Tarigan, R. (2008). " Kendala dan solusi pembelajaran sastera lama dan sastera modern" dlm. Jurnal Dinamika. Edisi Mei-Agustus. 6:2.

Trianton, Teguh. (2008). " Problem Pengajaran Sastra di SMK” dlm. Jurnal INSANIA. Sekolah Tinggi Agama Islam Negeri Purwokerto. 13:3. 341-354.

Widyastono, Herry.(2014). Pengembangan Kurikulum di Era Otonomi Daerah. Jakarta: Bumi Aksara. 